\title{
EPISTEEMILISTEST MODAALPARTIKLITEST EESTI KIRJAKEELES
}

\author{
Annika Valdmets ja Külli Habicht \\ Tartu Ülikool
}

Kokkuvõte. Artikli eesmärgiks on kirjeldada mõningate episteemiliste, tõeväärtushinnangut kandvate modaalpartiklite kujunemist ja kasutamist eesti (kirja)keeles. Täpsema vaatluse all on sõnad nagu kahtlemata, loomulikult, põhimõtteliselt ja tegelikult, mis on peamiselt viimase sajandi vältel arenenud täistähenduslikest viisiadverbidest modaalpartikliteks. Selle protsessi käigus on teisenenud nende semantilised, morfosüntaktilised ja pragmaatilised omadused. Käsitletavad üksused on tänapäeva eesti keeles polüseemsed: olenevalt kontekstist saab neid kasutada nii täistähenduslike viisiadverbide kui ka mittetäistähenduslike episteemiliste partiklitena. Episteemiliste modaalpartiklite kirjeldamisel on kaasatud ka subjektiivsuse ja intersubjektiivsuse mõisted. Artiklit illustreerivad näited Tartu Ülikooli kirjakeele korpustest ja vanadest eesti keele grammatikatest.

Märksõnad: episteemilised modaalpartiklid, grammatisatsioon, (inter)subjektiivsus, eesti kirjakeel

\section{Taust ja põhimõisted}

Partikliteks loetakse morfoloogiliselt muutumatuid keeleüksusi, tavaliselt süntaktiliselt sõltumatuid abisõnu (modaaladverbe, afiksaaladverbe, interjektsioone, konjunktsioone ja adpositsioone). Episteemilised modaalpartiklid (mh nt vaevalt, ilmselt, tõenäoliselt) on semantiliselt abstraktsed ja süntaktiliselt võrdlemisi vabad ning moodustavad osa suuremast partiklite rühmast, kuhu kuuluvad ka artiklis vaadeldavad üksused. Episteemilised partiklid ei ole omaette lauseliikmed, vaid neid saab lausesse lisada või sealt välja jätta, ilma et lausesisu muutuks. Need partiklid funktsioneerivad lauses üldlaiendina, lisades väljendatule modaalse tähenduse. Episteemiliste partiklite olulisim funktsioon avaldub just pragmaatilisel tasandil, sest nad lisavad lausele eri tüüpi subjektiivsete 
suhtumiste või tõekspidamistega ning tõeväärtushinnangutega seotud modaalseid tähendusi, mis võivad lähtuda kas ainult kasutajast (subjektivisatsioon) või hõlmata nii kasutajat kui ka vastuvõtjat (intersubjektivisatsioon). Modaalpartikleid, k.a episteemilisi partikleid, iseloomustab eri keeletasanditel järgmine tunnustekimp:

- foneetiline tasand: suund foneetilise lihtsustumise, lühenemise poole

- morfoloogiline tasand: muutumatu, morfoloogiliselt liigendamatu üksus; suund suletud sõnaklassi suunas

- süntaksitasand: mittelauseliikmeline, lause argumentstruktuurist sõltumatu üksus; vaba ümberpaiknemise võimalus

- semantikatasand: raskesti määratletav leksikaalne tähendus

- pragmaatikatasand: kontekstisidus, (inter)subjektiivse funktsiooniga üksus

Ennekõike semantika- ja pragmaatikatasandil toimunud ümbertõlgendus ehk reanalüüs on tekitanud olukorra, kus sama kirjapildiga üksused võivad täita lauses erinevaid funktsioone sõltuvalt nende pragmaatilisest tõlgendusest. Üksus võib olla kas leksikaalselt raskesti määratletava sisuga modaalpartikkel, mida on tänu selle lausegrammatilisele funktsioonile võimalik pidada grammatikaüksuseks, või omaette leksikaalse tähendusega ning lausega süntaktiliselt seotud adverb (määrus), mida pole võimalik lausest välja jätta ilma lausesisu muutuseta. Adverbid on semantiliselt täistähenduslikud ja süntaktiliselt lauseliikmelised üksused, mille kohta on võimalik esitada küsimus (nt kuidas? või kuivõrd?). Adverbid kuuluvad avatud sõnaklassi ning foneetiline lühenemine ei ole neile omane. Näitlikustamiseks on toodud kaks lauset sõna loomulikult kasutamise kohta. Esimeses lauses on tegemist adverbilise kasutusega (a), sest tegemist on küsimusele kuidas? vastava sõnaga, mille lausest väljajätmine muudaks propositsiooni, ning teises modaalpartiklilisega (b), mille puhul üksus ei ole küsimustatav ja täidab vaid modaalset funktsiooni. Sellise üksuse väljajätmine ei mõjuta propositsiooni.

(a) See naine sünnitas loomulikult.

(b) Sa võid loomulikult siia ööseks jääda. 
Artiklis selgitatakse partiklite kujunemist ja kasutusvõimalusi grammatisatsiooniteooria põhjal, jälgides lisaks ka grammatisatsiooniga kaasnevat (inter)subjektivisatsiooni. Grammatisatsiooni eelduseks on see, et areng toimub suurema grammatilisuse suunas ja saab alguse leksikaalselt täistähenduslikust lähteüksusest, mis reanalüüsitakse teatud kontekstides uue, endisest grammatilisema funktsiooni täitjaks. Kuigi artiklis esitatav näitematerjal on koondatud partiklite kujunemist ja kasutamist silmas pidades, seletab episteemilisi partikleid kirjeldav osa muuhulgas ka modaalpartiklite piiritlemise probleeme.

Artiklisse võetud lausenäited on pärit Tartu Ülikooli eesti kirjakeele korpuse 1890.-1990. aastate ilukirjanduslikest ja ajakirjanduslikest tekstidest ning 2000. aastate ajakirjandustekstidest $^{1}$. 2000. aastate ilukirjanduse näited on valitud tasakaalus korpusest ${ }^{2}$. Materjali uurides on jälgitud ka diakroonilist arengut ning kõiki siin näidetena esitatud üksusi on otsitud ka vana kirjakeele korpusest, mis hõlmab tekste 16. sajandist kuni 19. sajandi keskpaigani. Ilmne on aga see, et siin peamiselt vaadeldavad lt-liitelised määrsõnad, mis on hilisema kasutuse käigus reanalüüsitud modaalpartikliteks, on kirjakeelde tulnud alles 19. sajandi lõpu, 20. sajandi alguse intensiivse teadliku sõnavararikastamise käigus ega esine vanas kirjakeeles.

\section{Grammatisatsioonist}

Grammatisatsiooniteooriat kui selliseid keelemuutusprotsesse kirjeldavat teooriat, mille käigus leksikaalne või vähem grammatiline üksus muutub kasutuse käigus grammatilisemaks, on võimalik rakendada ka modaalpartiklite kui lausegrammatiliste üksuste kujunemist jälgides.

Grammatisatsiooni kui pankroonilist protsessi on uuritud, hõlmates nii diakroonilist muutumist kui ka sünkroonilist varieerumist. Diakrooniline lähenemine käsitleb keeleainese

1 Eesti kirjakeele korpus; http://www.cl.ut.ee/korpused/kasutajaliides/

2 Tasakaalus korpus; http://www.cl.ut.ee/korpused/grammatikaliides/ 
muutumist ajas leksikaalsest grammatilisemaks. Sünkroonilises plaanis käsitletakse keelekasutuse varieerumist, mille puhul võib sama keeleüksus olla paralleelselt tarvitusel nii leksikaalses kui ka grammatilises funktsioonis. Oma põhiolemuselt on grammatisatsioon siiski diakrooniline ja selle raames vaadeldakse keeles toimunud muutusi kahe või enama ajahetke vahel. (Hopper, Traugott 2003: 2 ja Heine 2003: 575)

Grammatisatsiooni on peetud ühesuunaliseks protsessiks, kuna see algab enamasti konkreetsetest leksikaalsetest üksustest ja lõpeb ideaalplaanis kogu ainese kaoga. See tähendab, et üksused kaotavad protsessi käigus üha rohkem semantilist ja foneetilist ainest ning n-ö lõpuni kuludes võivad asenduda uute üksustega. Siiski võib grammatisatsiooniprotsess igal ahela astmel lõppeda ning vanad vormid ei asendu ilmtingimata uutega. (Heine, Kuteva 2002: 4-5) Sellise lõpuni jõudnud protsessi näide on võimalik tuua vanadest eesti keele grammatikatest, mis osutavad, et keeles on kasutusel olnud iroonilist suhtumist väljendav modaalpartikkel seba $(<$ demonstratiivpronoomen see + rõhuliide $*-p A$, mis on hiljem lühenenud $p$-kujuliseks), nt sebba (mo) assi 'õige mu(l) asi' (Stahl 1637, Göseken 1660 ja Thor Helle 1732), sebba mo willi 'õige mul vili' (Thor Helle 1732). Hiljem on partikkel kaotanud iroonilise varjundi (seep' see asi ongi) ning on tänapäeva kirjakeeles aktiivsest kasutusest taandunud. Selle asemel võidakse kasutada nt partikleid õige, kah (õige/kah mu asi) vms.

Grammatisatsiooni käigus toimuv muutumine ei ole aga järsk. Keeleaines ei liigu kiiresti ühest kategooriast teise, vaid läbib oma kujunemisteel mitmeid väikeseid üleminekuid. (Hopper, Traugott 2003: 6) Foneetilise ainese muutumine on kõige kergemini jälgitav, sest sellega kaasneb ainese kadu. Üksuse kirjapildi lühenemine aga normikirjakeelde eriti hõlpsasti ei kandu, seega tuleb muutustega kursis olemiseks jälgida ka toimetamata tekste ja suulist kõnet. Nii on võimalik tänapäeva internetikeeles, mis kujutab endast omapärast suulise ja kirjaliku keele sulamit, märgata selliseid partiklilisi esinemusi nagu tegelt 'tegelikult', põmst 'põhimõtteliselt', suht 'suhteliselt', absull 'absoluutselt' jne. 
Heine ja Kuteva sõnastavad neli peamist omavahel tihedalt seotud grammatisatsiooni mehhanismi: desemantiseerumine, ekstensioon, dekategoriseerumine ja erosioon (Heine, Kuteva 2002: 2). Hopper ja Traugott nimetavad morfosüntaktiliste ja fonoloogiliste muutuste põhimehhanismideks reanalüüsi ja analoogiat (Hopper, Traugott 2003: 39). Olenemata sellest, kumba kirjeldust eelistada, on need vajalikud pidepunktid, seletamaks episteemiliste partiklite arengut eesti keeles. Iga mehhanism sisaldab kolmeastmelist üleminekumudelit, kus keeleväljend A (lähe) hakkab mingis kindlas kontekstis grammatiseeruma. Seejärel saab see uue kasutusmustri B (siht), kusjuures vaheastmena esineb A ja B varieeruvat kasutamist. Lõppstaadiumis keeleväljend A kaob, kasutusele jääb ainult B. Ajalooliselt vaadatuna võib juhtuda, et faas, kus A ja B eksisteerivad koos, kestab sadu aastaid, sest keeltes on tavaline, et ühe domeeni piires esineb varieeruvust. Kolmandas staadiumis keeleväljendi lähteüksust enam kasutusel pole. Kõik grammatiseeruvad keeleüksused siiski kolmandasse staadiumisse ei jõua. (Heine 1993: 48-49, Hopper, Traugott 2003: 49, 124-125) Sellise kolmandasse staadiumisse jõudnud partikli näiteks võiks olla juba 17. sajandi tekstides esinenud eituspartikkel teps 'üldse mitte', mis on tänapäevani kirjakeeles säilinud. Lähtekuju mitte eps ei ole juba vanas kirjakeeles enam kasutusel ning ka tänapäeva keele seisukohast ei ole see läbipaistev. Ka partikkel teps ise mõjub tänapäeva kirjakeeles pigem arhailisena ning on taandumisstaadiumis.

Paralleelselt kaht või enamat keelt uurinud teadlased on näidanud, kuidas sarnased leksikaalsed üksused läbivad sarnaseid grammatisatsiooniahelaid isegi mittesugulaskeeltes. Nii on siingi uuritavate partiklite puhul võimalik paralleele tõmmata teiste keeltega. Praegu on eesti keele suurimaks mõjutajaks inglise keel, kuid kuni 19. sajandi lõpuni oli määrav saksa keele mõju. Et tekste tõlgiti peamiselt saksa keelest, tuleb kõne alla ka partiklite tõlkeline laenamine (vt Habicht 2009). Üksüheselt kattuvaid ahelaid pole võimalik välja tuua, kuid makrotasandil on pilt sarnane (nt ingl actually, sks wirklich 'tegelikult', vn абсолютно, ingl absolutely 'absoluutselt'; ingl practically, sks praktisch 'praktiliselt'). 


\section{3. (Inter)subjektiivsusest}

Modaalpartiklite olemust kirjeldades tuleb kaasata ka subjektiivsuse (sh subjektivisatsiooni) ja intersubjektiivsuse (sh intersubjektivisatsiooni) mõisted. (Inter)subjektivisatsioon võib ilmneda koos grammatisatsiooniga. Subjektiivsus hõlmab ühelt poolt inimese enesetunnetust, teisalt ka kõneleja vaatepunkti diskursuses. Modaalsus ongi valdkond, mille kaudu on subjektiivsust keeles ilmselt enim uuritud. (Finegan 1995: 1-5, Shindo 2009: 75 ja Cuyckens jt 2010: 1) Kõneleja või kirjutaja ei otsusta mitte ainult öeldu sisu üle, vaid ka selle käigus toimivate keeleliste valikute üle. S.t kõneldes või kirjutades tehakse valikuid, mis võivad olla subjektiivsed. Valitakse näiteks, millist ajavormi kasutada, milline üksus paigutada (süntaktilise) subjekti rolli jne. Neid valikuid võib suunata konkreetne register (nt akadeemiline/ametlik vs mitteametlik situatsioon), kus kõneldakse või kirjutatakse. Kui samal ajal peetakse silmas ka adressaati, siis on omakorda tegemist intersubjektiivsusega. (Traugott, Dasher 2002: 20-21)

Subjektiivsuse ja intersubjektiivsuse mõistete kasutamine on keeleteaduses algselt seotud Émile Benveniste'i nimega (vt Benveniste 1971 [1966]: 204, 225-230). Peamised subjektivisatsiooni käsitlevad uurimissuunad on sõnastanud Traugott ja Langacker ning need on oma olemuselt mõnevõrra erinevad. Traugotti lähenemises (mh Traugotti ja Dasheri teoses (2002)) väidetakse, et nimetatud lähenemine on diskursusepõhine, (inter)subjektivisatsioon viitab asjaolule, et mingi lingvistilise üksuse tähendustel on kalduvus muutuda järjest subjektiivsemaks. Langackeri (2006: 18; vt ka üldiselt Athanasiadou jt 2006) arvates pole põhjust rääkida tähenduse subjektiivsuse määrast, vaid tuleks uurida konkreetse üksuse staatust üldises situatsioonis. Üks tähendus sisaldab tema arvates alati nii subjektiivselt kui ka objektiivselt tõlgendatavat elementi, kusjuures nende elementide tõlgendatavus subjektiivseks või objektiivseks võib aja jooksul muutuda. Mõlema suuna esindajad seovad oma käsitlused grammatisatsiooniga, Langackeri käsitlusest jääb enamasti aga kuulaja/lugeja roll välja. Siinses artiklis lähtutakse 
modaalpartiklite olemuse kirjeldamisel Traugotti (ja Dasheri) käsitlusest (vt ka Traugott 2010), mille järgi väljendab kõneleja või kirjutaja subjektiivsuse abil oma vaatenurka; intersubjektiivsust vaadeldakse subjektiivsusega paralleelselt - kui kõneleja või kirjutaja otsest suhestumist kuulaja või lugejaga sotsiaalses või episteemilises plaanis (Traugott, Dasher 2002: 21-22, Traugott 2003: 128 ja Park 2010: 127-129).

Traugotti järgi kujuneb intersubjektiivsus subjektiivsusest. Neid käsitletakse enamasti semantilise muutusena ahelas mittesubjektiivne $>$ subjektiivne $>$ intersubjektiivne. Subjektiivsete üksuste hulka kuulub ka siinses artiklis käsitletavate sarnaseid: nt vastandavad partiklid siiski, ausalt (öeldes), ilmselgelt jne väljendavad kõneleja või kirjutaja suhtumist öeldu sisusse, diskursusepartiklid õigupoolest, täpsemalt jt märgivad kõneleja või kirjutaja arusaama, et kaks propositsiooni on omavahel seotud, ja skalaarsed üksused ainult, isegi jt kajastavad keelekasutaja suhtelist hinnangut mingi kindla hulga piirides. (Traugott 2003: 124-128) Intersubjektiivsus, mida samuti on erinevad autorid mõnevõrra erinevalt tõlgendanud (vt lisaks nt Nuyts 2001: 394-397 ja Verhagen 2005: 16jj), on nähtus, mille puhul kõneleja/kirjutaja hõlmab kuulaja/lugeja konkreetsesse kõneakti, mitte kirjeldatud olukorda. S.t vaatluse all ei ole kõik situatsioonid, kus vihjatakse teisele isikule või pöördutakse tema poole, vaid tähtis on teatud suhtumise väljendamine (adressaadi suunas) ja ka adressaadi minapilt. Siinkohal on näiteks sinatamise või teietamise vahel valimine (sotsiaalses plaanis) või modaalsõnade kasutamine öeldu sisule suhtumisvarjundi andmiseks (episteemilises plaanis). Need valikud on nii subjektiivsed, lähtudes kõneleja vaatenurgast, kui ka intersubjektiivsed, sõltudes kõneleja kujutlusest, milline on viimase suhe vestluskaaslasega ning millised on vestluskaaslase ootused. Seega ilmneb intersubjektiivsus alati koos subjektiivsusega ja intersubjektivisatsiooni võib käsitleda ka kui subjektivisatsiooni üht haru, mitte kui eraldi mehhanismi. (Traugott 2003: 128-129) Subjektiivsust aluseks võttes on võimalik eristada partikleid adverbidest, kuna subjektiivsuse abil annab kirjutaja/kõneleja edasi oma vaatenurka olukorrale. Siinses näites on kahtlemata puhul tegemist 
subjektiivse partikliga, mis väljendab kirjutaja kindlust öeldu sisus - öeldu kehtib suure tõenäosusastmega.

End kahtlemata professionaaliks pidades tähtsustas ta informatsiooni kogumist, selle töötlemist, kontrollimist, klientuurile serveerimist ja realiseerimist (ILU1990〈ilu0609).

Partikkel tegelikult sobib nii subjektiivsuse kui ka intersubjektiivsuse näiteks (vt ka Traugott 2003), kuna selle abil saab väljendada nii oma vaatenurka öeldule (subjektiivsus) kui ka otsest suhestumist adressaadiga (intersubjektiivsus). Tavaliselt toimib see grammatiseerunud üksus subjektiivsena, kandes episteemilist funktsiooni. Mõnel tarvitusjuhul on aga tegelikult tõlgendatav intersubjektiivsena. Vt nt lauset

Ma tahtsingi tegelikult su ees vabandada (Rein Veidemann 2003, Lastekodu. Memorandum).

Siinses lauses on üksus tegelikult kasutusel partiklina, mis liigub lauses vabalt. Autor on asetanud tegelikult lause keskele, kuid vaid üksiklauset vaadates ei muutuks funktsionaalselt midagi, kui partikkel paikneks lause alguses (nt Tegelikult ma tahtsingi su ees vabandada) või lause lõpus (nt Ma tahtsingi Su ees vabandada tegelikult). Kui aga modaalsus lausest eemaldada ja jätta alles vaid informatiivne kese (Ma tahtsin su ees vabandada), siis lause mina-isik ei pööra tähelepanu adressaadile, vaid annab edasi mingit ,teadet", hoolimata sellest, et adressaat on lauses olemas. Lisades lausele tegelikult, väljendatakse adressaadile kõneleja suhtumist. Lauses (Tegelikult) ma (tegelikult) tahtsingi (tegelikult) su ees (tegelikult) vabandada (tegelikult) on adressaat kaasatud situatsiooni - partikli abil pehmendatakse öeldut, kuna kõneleja/ kirjutaja arvates võib adressaadil olla olukorrast mingisugune oma arusaam (nt kõneleja arvab, et adressaat ootab vabandust) ${ }^{3}$.

3 Tegelikult positsioneerimine lause alguses võib laiemat konteksti vaadates muuhulgas viidata sõna funktsioneerimisele diskursusemarkerina, kuid siinses artiklis jäetakse sellised esinemised tähelepanuta ja keskendutakse episteemilistele juhtudele. 
Eesti keeles on levimas ka üksus ilmselgelt, millel on peale episteemilise ka evidentsiaalne varjund (kasutuses 'kõigile on ilmne et $X^{\prime}$ ). Sellisel juhul on see interpreteeritav pigem intersubjektiivseks kui subjektiivseks üksuseks, nagu võib järeldada järgnevast näitest.

Kadunud on ka pruunid meesteülikonnad, mis sel hooajal on ilmselgelt out (AJAE1990\stak0379).

Selle lause tõlgendamisel on oluline pragmaatiline üldistus, vastuvõtjaid hõlmav eeldatav ühine seisukoht.

\section{Modaalpartiklite koht keelesüsteemis}

Erinevate keelte käsitlustes tarvitatakse terminit partikkel mõnevõrra erinevalt (vt ka Watts 1988: 236-240)4 ${ }^{4}$ Üldistavalt võib aga öelda, et kõikide keelte partiklid kui grammatilised üksused kujunevad keele olemasoleva materjali süntaktilise ja semantilise ümbertõlgendamise teel (Eckardt 2006: 49). Selliste üksuste alla loetakse tihtipeale kõiki neid signaale, millel on mingisugune mõju lause/lausungi kommunikatiivsel tasandil; nendele vastandub lause propositsiooniline külg (Fraser 1996: 168). Täpse terminoloogia väljatöötamine pole siinse kirjutise eesmärk, kuid see tuleb edaspidi vaatluse alla võtta, sest selle temaatikaga seotud oskussõnadel on autoriti erinevaid tähendusnüansse. Siinses artiklis püütakse järgida terminoloogiat, mida autorid on oma teostes pakkunud, jättes kõrvale erinevad tähendusvarjundid.

4 Ingliskeelses kirjanduses kasutatakse siin modaal- jm partiklitena defineeritud üksuste kohta mitmeid erinevaid termineid, muuhulgas nt modaalpartikkel (modal particle), modaaladverb (modal adverb), täitesõna (filler), diskursusemarker (discourse marker), diskursusepartikkel (discourse particle), pragmaatiline partikkel (pragmatic particle) jms. Kõikidel neil terminitel on oma tähendusvarjund. Laialt käsitletuna võidakse partikliteks nimetada kõiki muutumatuid sõnu, niisiis sealhulgas adverbe. Kitsamas tähenduses on partiklite hulka loetud muutumatud sõnad, mis pole prepositsioonid, konjunktsioonid ega adverbid (ka siin lähenetakse probleemipüstitusele kitsamas tähenduses). 
Episteemilise modaalsusega väljendab kõneleja oma arvamust propositsiooni staatuse kohta. Episteemilisus erineb evidentsiaalsusest, kus osutatakse tõenditele ehk sellele, kellelt esitatud informatsioon pärineb. Siiski käsitletakse episteemilist ja evidentsiaalset modaalsust tihti koos, sest need ei pruugi vormiliselt eristuda. (Palmer 2001: 8) Siinses artiklis käsitletakse episteemilisi partikleid ${ }^{5}$ kui fraasi- või lauselaiendid, mis piiritlevad lause tähendust. Episteemilistest partiklitest ei ole võimalik loomulikus keelekasutuses moodustada selliseid keeleüksusi, mis oleksid eitatuna vastandsisulised (*ebategelikult, *mittepõhimõtteliselt). Isegi kui nimetatud vorm oleks grammatiliselt korrektne (ebapraktiliselt, ebaloomulikult), ei saaks seda kasutada partiklina. Kuna modaalpartiklid pole ka iseseisvad lauseliikmed, ei saa nende kohta sisulist küsimust esitada. Nt esimeses lauses on võimalik adverbi põhimõtteliselt kohta esitada küsimus kuidas? Teises lauses kasutatud üksust küsimustada ei saa.

Teadlased väidavad, et naised ei jagune sünnitajateks ja aborditegijateks - nendeks, kes põhimõtteliselt lapsi ei taha (EPL 01.03.2005, Kristina Täht, Meie vanemad ütlesid meile ,jaa").

Peab kohe ütlema, et Vahemere kultuuriruumis pole selles põhimõtteliselt midagi skandaalset (peaasi on säilitada macho hoiak), kuid tema balansseeris siiski skandaali piiril (Emil Tode 2002, Raadio).

Partiklite kategooriasse kuulub palju difuusset ainest. Samakujulistel keeleüksustel võib olla mitmetine tähendus, mis

5 Laurel Brinton soovitab oma teoses kasutada uuritud keeleainese nimetamiseks terminit (pragmaatiline) marker ja eelistada seda terminitele sõna või partikkel, kuna nimetus marker ühendaks endas nii ühesõnalised üksused kui ka fraasid (Brinton 1996: 29-30). Kuna aga siinses käsitluses on vaatluse all üksikud sõnad, mitte fraasid, siis kasutatakse peaasjalikult terminit partikkel. Uuritavate üksuste laiemaid terminoloogilisi ja kuuluvuslikke probleeme siinses artiklis ei lahata. 
sõltub kontekstist. (Aijmer 2002: 28) Modaalsõnade mitmetähenduslikkuse küsimust käsitlevad autorid erinevalt, siinkohal lähtutakse Paul J. Hopperi esitatud astmelisest mudelist (1991: 22-24), mis näitab, kuidas konkreetne kasutusmuster areneb suunal A > B, kus A ja B võivad mingil etapil ka koos eksisteerida (ingl layering). Seega on aluseks võetud ainese polüseemne (mitte homonüümne) käsitlus. Kaht polüseemset üksust ühes ja samas lauses kõrvutades tuleb nende erinevus hästi esile, kuigi eriti tavapärane selline kooskasutus pole. Järgmises näitelauses on vaatluse all olevat üksust kasutatud nii modaalse partiklina kui ka viisiadverbina: esimene suhteliselt on määratletav partikliks (parafraseeritavaks sõnaga üsna, mis väljendab skalaarsena kõneleja hoiakut) ning teine viisiadverbiks (vastandub täistähenduslikule adverbile absoluutselt ning vastab küsimusele $k u i$ das?). Täistähenduslikku kasutust eristab partiklilisest ka see, et esimene on lauses rõhutatud, teine rõhutamata.

Siiani on asjad end päris kiiresti ära tasunud ja ka kasum on suhteliselt märkimisväärne, seda muidugi suhteliselt, trykikuludega võrreldes (AJA1990\re0209).

Episteemilisi partikleid kirjeldatakse niisiis kui leksikaalselt pigem tühjasid üksusi, mis asuvad sõnaliikide äärealal, liiguvad süntaktiliselt vabalt ning on tekstis fakultatiivsed. Modaalpartiklitel on oluline koht interpersonaalsel tasandil: kõneleja subjektiivse suhtumise väljendamisel ning dialoogi puhul kõneleja ja kuulaja vahelise läheduse loomisel (vt ka selgitust (inter)subjektiivsusest). (Brinton 1996: 6, 62-65 ja Aijmer 2002: 2) Võrrelgem kaht üksiklauset, millest esimeses on üksus loomulikult algses leksikaalses kasutuses ja teises grammatiseerunud modaalpartikliks. Teises lauses on loomulikult fakultatiivne üksus, mis liigub piirangutetasiin võiks see olla mis tahes positsioonis (lause alguses, keskel või lõpus), ilma et lause põhistruktuur muutuks. Ka partikli enese funktsioon jääks seejuures samaks.

Laiade eluwiisidega Wieni moodiasjade tegija „Mizi” (neiu E. Annuk) oli kohati õige loomulikult joonistatud 
kuju, kuid hakatuses kõlas ta naer otsitult ja närwiliselt (AJA1910|wi0301).

Põgusas intervjuus seda kõike loomulikult haarata ei suuda (AJA1970\km0005).

Episteemilised partiklid kui diskursuspragmaatilised üksused on metatekstuaalsed, s.t nende funktsiooniks on lisada tekstile mingisugune kommentaar. Samuti on need deiktilised, viidates kõneleja/kirjutaja metatekstuaalsele hoiakule ja püüdes vastuvõtjat juhtida sama hoiaku suunas. (Traugott 1999: 181) Niisiis kasutatakse neid üksusi, et „väljendada nõustumist või mittenõustumist, veendumust või kahtlust, toetust või tagasilükkamist, tõekspidamist või kõhklust, ning nende abil võib edasi anda, kas informatsioon on uus või vana, üllatav või triviaalne jne" (Andersen 2001: 71). Järgnevas näites püüab lause autor rõhutada adressaadiga ühisel arvamusel olemist, s.t viidatakse jagatud seisukohale, mis võiks hõlbustada järgnevat suhtlust.

Tegemist on lihtsalt talviste sõidutingimustega, mis on loomulikult suvistest halvemad (EPL 02.02.2001, Laur Koni, Kommunaalamet: Ummikuid ei ole).

Modaalpartiklid on keeltes tihtipeale läbinud grammatisatsiooni, arenedes propositsionaalsest tähendusest pragmaatilisema poole. Nende kujunemisprotsess on ühesuunaline, kuid mitte alati sirgjooneline. Tavaliselt liigub keeleüksus ahelas mittepragmaatilisest (või vähem pragmaatilisest) pragmaatilisema suunas, kuid erinevate üksuste kujunemine võib olla mõnevõrra erinev. Seetõttu tulebki iga üksikjuhtumit käsitleda eraldi. (Brinton 1996: 275) Partiklite kujunemislugu põhjendab nende vajadus olla informatiivne, kergesti kasutatav ja ekspressiivne. Nad lisavad lausele värvingut, andes edasi lause/lausungi autori suhtumist, hoiakuid ja väärtushinnanguid. Partiklid rõhutavad kas kogu lausesisu või mõnda osa sellest. (Habicht 2009: 608-609) Esimeses näites on tegemist üldlaiendiga, mis annab värvingu kogu lausele, teises rõhutab sõna julgelt vaid fraasi. Üksuse 
grammatilisus suureneb siin koos mõjuala suurenemisega, ehkki grammatiseeruva üksuse puhul on ühesuunalisuse hüpoteesist lähtudes tavaliseks peetud just mõjuala järkjärgulist vähenemist (vt nt Lehmann 1995). Siinses artiklis käsitletud pragmaatiliste markerite puhul näib tegemist olevat mõnevõrra eripärase semantilise ja süntaktilise reklassifitseerimise juhtumiga, mida on ka varem kirjeldatud (vt nt Tabor, Traugott 1998).

„See võtab sada kolmkümmend julgelt sisse, kui tarvis," kiitis Simmo ja ta käsi puudutas valmisolevalt käigukangi (Lehte Hainsalu 2003, Sul on teine).

Veel võiks lisada, et julgelt pool Pirosmani sööjaskonnast näivad samuti grusiini verd olevat (EPL 01.04.2000, Helle ja Heino Ranskalainen, Vahetan pizza kaukaasia hatshapuri vastu).

Eelnevat kaht lauset järgnevaga kõrvutades on lihtne märgata funktsionaalset erinevust: järgmises näites laiendab julgelt täistähendusliku määrsõnana ühendverbi üles astuma.

Mitte metsaliselt ei ole meie mõisnikkude kallale läinud, waid metsikute mõtete wastu julgelt üles astunud, kuna mõistlikkudele mõtetele õiglaselt kiitust awaldasime (AJA1890\pos0901).

Pragmaatilised markerid kuuluvad Brintoni järgi peamiselt suulisesse diskursusesse ja on sagedase esinemusega mitteobligatoorsed üksused. Nende kasutamine viitab eelkõige informaalsele situatsioonile. Siiski esineb pragmaatilisi markereid ka kirjalikus keeles, kuid need võivad olla suulise kõne omadest erinevad. Samuti võivad erineda kirjaliku keele pragmaatiliste markerite kasutamise põhjused. Pragmaatilised markerid on lühikesed üksused, mis on tihtipeale fonoloogiliselt redutseerunud ja rõhuta. (Brinton 1996: 33-34) Ka eesti kirjakeele episteemilised partiklid kuuluvad seda tüüpi täiteüksuste hulka, mida oleks võimalik lausest välja jätta. Väljajätt ei muudaks lause sisu 
ning lause ei mõjuks ebagrammatilisena, kuid tõlgendus muutuks, kaoks osutus kirjutaja episteemilisele seisukohavõtule. Siinkohal on tegemist näitelausega 1990. aastatest, kuid tänapäevases internetisuhtluses võiks pikem vorm asenduda lühemaga: levinud on kujud põhimõtselt, põmst ja pmst.

Kui riik kuulutab tema omanduses olevatele riigiettevõtetele ja aktsiaseltsidele välja pankrotid, teeb ta seda põhimõtteliselt iseendale (AJA1990\ap0341).

Erinevatest analüüsikriteeriumidest hoolimata on episteemilisi partikleid kui grammatikaüksusi raske määratleda. Samuti pole neid üksusi nende spetsiifilise tähenduse tõttu lihtne teise keelde tõlkida. (Brinton 1996: 33-34) Keele emakeelena kõnelejad kasutavad selliseid sõnu tavaliselt kindlates kontekstides ning kindla suhtumisvarjundi edasiandmiseks (nt tegelikult on partikkel, mida kasutatakse erinevates olukordades: sekkumisel, parandamisel, öeldu pehmendamisel, kommenteerimisel). Kui muukeelne kõneleja pruugib partikleid valesti või ei kasuta neid oma kõnes üldse, võib tekkida isegi suhtlusraskusi. (Aijmer 2002: 3) Kuna suulise diskursuse jooned kanduvad eri tüüpi vahendusallkeelte kaudu pidevalt kirjakeelde, leidub modaalpartikleid rohkesti ka normikirjakeeles, mida siinses artiklis käsitletud eesti kirjakeele episteemiliste partiklite valik näitas.

\section{Kokkuvõtteks}

Artiklis vaatluse all olnud episteemilised partiklid on kujunenud grammatisatsiooniprotsessi põhimõtete kohaselt leksikaalsemast (konkreetsest täistähenduslikust) grammatilisema (abstraktsema mittetäistähendusliku) suunas. Siinses uurimuses on näidatud ka seda, kuidas (inter)subjektiivsus avaldub eesti keele modaalpartiklite süsteemis. Lisaks sellele on välja toodud tunnused, mille alusel partikleid adverbidest eristada. Artiklis näidetena esitatud üksused on arenenud täistähenduslikest viisiadverbidest ja muutunud reanalüüsi käigus modaalseteks, lau- 
sele või fraasile kõnelejapoolset tõeväärtushinnangut lisavateks partikliteks. Seetõttu on nende iseloomulikke tunnuseid ülevaatlik määratleda just täistähenduslikele adverbidele vastanduvalt. Heine ja Kuteva on (2007: 34) välja toonud, et grammatisatsioon põhineb pragmaatika, semantika, morfosüntaksi ja foneetiliste faktorite koostoimel (pleekimine seostub semantikaga, ekstensioon pragmaatikaga, dekategoriseerumine morfosüntaksiga ja erosioon foneetikaga). Igaüks neist on seoses ühe eespool kirjeldatud grammatisatsiooni mehhanismiga ja seega võib üldistavalt öelda, et partiklite grammatisatsioon on kirjeldatav kõigi nende tasandite kaudu. Grammatisatsiooniga on seotud veel teisedki keelemuutusprotsessid - siinses käsitluses peatuti täpsemalt (inter)subjektivisatsioonil, mis hõlmab nii kõneleja/kirjutaja enese kui ka vastuvõtja subjektiivseid hoiakuid väljendatava lausesisu suhtes. Kui lauses on modaalsust väljendatud partikli abil, siis vastandades lause propositsioonilist külge episteemilisega, on modaalne üksus võimalik välja jätta. Lause informatiivne külg selle tagajärjel ei muutuks, küll aga teiseneks öeldu suhtumisvarjund. Episteemiliste partiklite näol on eesti kirjakeeles tegemist vajalike ja sagedaste üksustega, mis võimaldavad väljendada (inter)subjektiivset suhtumist väljendatu tõeväärtusesse. Seda tüüpi partiklite põhiliseks määratlemise aluseks on kontekstiline tõlgendamine, sest otseseid vormilisi eristuskriteeriume ei ole. Polüseemsete adverbide ja modaalpartiklite vahel aitab vahet teha nende küsimustamine (modaalpartiklid on küsimustamatud), rõhutatuse jälgimine (modaalpartiklid ei esine lauses rõhulises positsioonis), eituse korral vastandsisuliste üksuste loomise võimalikkus (modaalpartiklite puhul pole see võimalik) ning lauses vaba ümberpaiknemise või väljajätu võimalus (modaalpartiklit on võimalik lausest välja jätta ilma propositsiooni muutmata). Kirjakeelt diakrooniliselt jälgides võib öelda, et episteemilised partiklid on täienev ja ajas muutuv sõnarühm. 


\section{Aadressid:}

Annika Valdmets, Külli Habicht

Eesti ja üldkeeleteaduse instituut

Tartu Ülikool

Jakobi 2, 51014 Tartu

E-mail: Annika.Valdmets@ut.ee, Kylli.Habicht@ut.ee

\section{Kirjandus}

Aijmer, Karin (2002) English discourse particles: evidence from a corpus. Amsterdam and Philadelphia: John Benjamins.

Andersen, Gisle (2001) Pragmatic markers and sociolinguistic variation: a relevance-theoretic approach to the language of adolescents. Amsterdam and Philadelphia: John Benjamins.

Athanasiadou, Angeliki, Costas Canakis, Bert Cornillie, eds. (2006) Subjectification: various paths to subjectivity. Berlin and New York: Mouton de Gruyter.

Benveniste, Émile (1971 [1966]) Problems in general linguistics. [Problèmes de linguistique générale.] Transl. by Mary Elizabeth Meek. Coral Gables: University of Miami Press.

Brinton, Laurel J. (1996) Pragmatic markers in English: grammaticalization and discourse functions. (Topics in English Linguistics, 19.) Berlin and New York: Mouton de Gruyter.

Cuyckens, Hubert, Kristin Davidse, Lieven Vandelanotte (2010) "Introduction". In Hubert Cuyckens, Kristin Davidse, Lieven Vandelanotte, eds. Subjectification, intersubjectification and grammaticalization, 1-26. Berlin and New York: De Gruyter Mouton.

Eckardt, Regine (2006) Meaning change in grammaticalization: an enquiry into semantic reanalysis. Oxford: Oxford University Press.

Eesti kirjakeele korpus. <http://www.cl.ut.ee/korpused/kasutajaliides/>. Vaadatud 29.10.2012.

Finegan, Edward (1995) "Subjectivity and subjectivisation: an introduction". In Dieter Stein, Susan Wright, eds. Subjectivity and subjectivisation: linguistic perspectives, 1-15. Cambridge: Cambridge University Press.

Fraser, Bruce (1996) "Pragmatic markers". Pragmatics 6, 2, 167-190.

Göseken, Heinrich (1660) Manuductio ad Linguam Oesthonicam, Anführung Zur Öhstnischen Sprache. Reval: Adolph Simon.

Habicht, Külli (2009) „Heinrich Stahli eripärased modaaladverbid”. Keel ja Kirjandus 8-9, 608-619.

Heine, Bernd (1993) Auxiliaries: cognitive forces and grammaticalization. New York and Oxford: Oxford University Press. 
Heine, Bernd (2003) “Grammaticalization”. In Brian D. Joseph, Richard D. Janda, eds. The handbook of historical linguistics, 575-601. Oxford: Blackwell.

Heine, Bernd, Tania Kuteva (2002) World lexicon of grammaticalization. Cambridge: Cambridge University Press.

Heine, Bernd, Tania Kuteva (2007) The genesis of grammar: a reconstruction. Oxford and New York: Oxford University Press.

Hopper, Paul J. (1991) “On some principles of grammaticalization”. In Elizabeth Closs Traugott, Bernd Heine, eds. Approaches to grammaticalization. Vol. 1: Focus on theoretical and methodological issues, 17-35. Amsterdam and Philadelphia: John Benjamins.

Hopper, Paul J., Elizabeth Closs Traugott (2003) Grammaticalization. 2nd ed. Cambridge: Cambridge University Press.

Langacker, Ronald W. (2006) "Subjectification, grammaticization, and conceptual archetypes". In Angeliki Athanasiadou, Costas Canacis, Bert Cornillie, eds. Subjectification: various paths to subjectivity, 17-40. Berlin and New York: Mouton de Gruyter.

Lehmann, Christian (1995) Thoughts on grammaticalization. München: Lincom Europa.

Nuyts, Jan (2001) "Subjectivity as an evidential dimension in epistemic modal expressions". Journal of Pragmatics 33, 383-400.

Palmer, Frank Robert (2001) Mood and modality. 2nd ed. Cambridge: Cambridge University Press.

Park, Chongwon (2010) "(Inter)subjectification and Korean honorifics". Journal of Historical Pragmatics 11, 1, 122-147.

Shindo, Mika (2009) Semantic extension, subjectification, and verbalization. Lanham: University Press of America, Inc.

Stahl, Heinrich (1637) Anführung zu der Estnischen Sprach. Revall: Chr. Reusner der älter.

Tasakaalus korpus. <http://www.cl.ut.ee/korpused/grammatikaliides/>. Vaadatud 29.10.2012.

Tabor, Whitney, Elizabeth Closs Traugott (1998) "Structural scope expansion and grammaticalization". In Anna Giacalone Ramat, Paul J. Hopper, eds. The limits of grammaticalization, 229-272. (Typological Studies in Language, 37.) Amsterdam and Philadelphia: John Benjamins.

Thor Helle, Anton (1732) Kurtzgefaszte Anweisung Zur Ehstnischen Sprache. Halle: Stephan Orban.

Traugott, Elizabeth Closs (1999) "The rhetoric of counter-expectation in semantic change: a study in subjectification". Andreas Blank, Peter Koch, eds. Historical semantics and cognition, 177-196. Berlin and New York: Mouton de Gruyter.

Traugott, Elizabeth Closs (2003) "From subjectification to intersubjectification". In Raymond Hickey, ed. Motives for language change, 124-139. Cambridge: Cambridge University Press.

Traugott, Elizabeth Closs (2010) “(Inter)subjectivity and (inter)subjectification: a reassessment”. In Hubert Cuyckens, Kristin Davidse, Lieven 
Vandelanotte, eds. Subjectification, intersubjectification and grammaticalization, 29-71. Berlin and New York: De Gruyter Mouton.

Traugott, Elizabeth Closs, Richard B. Dasher (2002) Regularity in semantic change. Cambridge: Cambridge University Press.

Verhagen, Arie (2005) Constructions of intersubjectivity: discourse, syntax, and cognition. Oxford and New York: Oxford University Press.

Watts, Richard J. (1988) "A relevance-theoretic approach to commentary pragmatic markers: the case of actually, really and basically". Acta Linguistica Hungarica 38, 1-4, 235-260.

\begin{abstract}
Annika Valdmets and Külli Habicht: About epistemic modal particles in Estonian. The purpose of this article is to give an overview of the development and use of some of the epistemic modal particles in written Estonian. More specifically, this paper detangles the topic with the examples of the words like kahtlemata 'undoubtedly', loomulikult 'of course', põhimõtteliselt 'in principle' and tegelikult 'actually', which are particles that have evolved from (manner) adverbs and, as polysemous items, are being used in both functions nowadays. During this evolution, the words' semantic, morphosyntactic and pragmatic properties have changed. The data for this study mainly come from the Corpus of Estonian Literary Language, the Balanced Corpus of Estonian, and old Estonian grammars. The theoretical background is based on grammaticalization approach. More specifically, the topics of subjectivity and intersubjectivity are examined in greater detail. The most important function of the particles studied here is indeed appearing on the pragmatic level because these items add epistemic modality to the clause which can only originate from the speaker/writer (subjectivity) or which can cover also the addressee (intersubjectivity).
\end{abstract}

Keywords: epistemic modal particles, grammaticalization, (inter)subjectivity, literary Estonian 